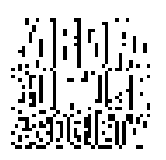

\title{
Marketing the beast: Left Behind and the apocalypse industry
}

\author{
Torin Monahan \\ VANDERBILT UNIVERSITY, USA
}

\begin{abstract}
And he causeth all, both small and great, rich and poor, free and bond, to receive a mark in their right hand, or in their foreheads: And that no man might buy or sell, save he that had the mark, or the name of the beast, or the number of his name. Here is wisdom. Let him that hath understanding count the number of the beast: for it is the number of a man; and his number is Six hundred threescore and six. (Bible, Revelation 13: 16-18)
\end{abstract}

The Second Coming evokes not a Jesus who saves, but one who pays dividends. Or, more accurately, one who promises a miraculous return on a limited spiritual investment. (Comaroff and Comaroff, 2000: 315)

Prophecies of the apocalypse circulate and multiply with incredible frequency, velocity and profitability. In some respects, concerns over the impending destruction of the world are ancient obsessions and well-worn mythological motifs, which wax and wane according to technological changes, historical contingencies or significant turning points on arbitrary calendars. On the other hand, contemporary apocalypse prophecies fuse in interesting - and perhaps indelible - ways with capitalist economies. Whether the looming disasters are technological, environmental or biblical, they tend to afford amazingly lucrative opportunities for some while fueling the increasing vulnerability of others. Jean Comaroff and John Comaroff (2000) label this emerging set of practices millennial capitalism, indicating a globalized, neoliberal form of capitalism predicated upon privatization, individual responsibility and the right to consume (not to produce). Especially for various end-of-days movements, this neoliberal logic introduces provocative dissonances between value placed on individual profit versus universal salvation, upon the medium versus the message. In some instances, religious warnings about the dangers of technology and the capitalist market are themselves highly mediated by technology and are enormously profitable ventures.

Media, Culture \& Society (C) 2008 SAGE Publications (Los Angeles, London, New Delhi and Singapore), Vol. 30(6): 813-830

[ISSN: 0163-4437 DOI: 10.1177/0163443708096095] 
An entire industry has developed to feed the fears of Christians, and presumably others, about the imminent coming of the Antichrist and the end of the world. As part of the $\$ 7$ billion market for Christian products (Business Week, 2005), religious fiction now occupies aisles upon aisles of bookshelves in some large chain bookstores. Much of this religious material demonstrates a significant degree of gloating by Christian authors over the presumably 'condemned' lapsed-Christians and nonbelievers who will remain on Earth to suffer after the rapture occurs. Apart from religious fiction, products in this genre include video games, board games, websites, DVDs, televised sermons and a host of 'nonfiction' books, which delineate in great detail the many forms that current and future threats upon souls can take, along with identifying the complicit parties involved in propagating the secular mechanisms and ideologies of damnation.

Particularly fascinating is the mobilization of discourse about the "mark of the beast', which singles out certain technologies for vilification and people for damnation. As referenced by the epigraph above, from the Bible's book of Revelation, the mark of the beast indicates a symbol that will be given to people during the Last Days before the Second Coming of Jesus Christ. From this perspective, whereas the mark will be required for people to engage in any form of capitalist exchange, such as might be necessary for general sustenance, in voluntarily accepting the mark, people will perforce align themselves with the Antichrist and doom themselves to perdition. The alternative, as many exegeses suggest, is to reject the mark, and thus commit oneself to dying miserably on Earth to enable the possibility of eternal life in heaven. Various technologies have been nominated by Christian groups as metaphorically representing or literally being the mark of the beast. Some of these include radio-frequency identification (RFID) chips implanted into individuals' arms, national identity card schemes, and even common barcodes or credit and social security cards. Given dominant cultural equations of technology with progress and social good, and especially with economic good, religious perspectives on technologies of production and consumption provide an especially rich terrain for investigating Christian modalities of millennial capitalism.

This article analyses the content and context of Left Behind, a popular series of Christian novels about the Last Days. First, it provides an overview of the book series and the philosophies that undergird it. Next, it describes three thematic areas where contradictions exist between the theological framework espoused by the novels and the practices of the novels' authors and key characters. These thematic areas include relations with the capitalist economy; perspectives on technologies of production, consumption and control; and orientations toward social problems. The overall argument is that contemporary 'rapture fiction' responds to and reproduces the crises and instabilities of modernity. It enacts a politics of consumerist and technological engagement 
alongside one of social disengagement. By rationalizing wealth disparities and religious inflexibility as part of God's plan, these politics may aggravate social inequalities, religious conflicts and cultural tensions.

\section{Rapture fiction}

The Left Behind story begins dramatically with the sudden and unexpected 'rapture' of saved souls, including all children, fetuses and true Christians (LaHaye and Jenkins, 2000a). As people disappear from vehicles, planes, streets, schools and homes, chaos erupts and disastrous accidents occur around the world. Those left behind are thrown into panic and shock, desperately trying to find their loved ones, their ways back home and viable explanations for where everyone went. The event of the rapture marks the starting point for the book series, as well as for the seven-year rule of the Antichrist. Operating to institute a 'world government' and a single world currency under the auspices of the United Nations (UN), the Antichrist, who is SecretaryGeneral of the UN, seeks to dominate all nations and make life a living hell for non-raptured, lapsed - or belatedly converted - Christians. According to the biblical prophecies embraced and reinterpreted by Left Behind, after seven years, Jesus Christ will return to slaughter all his enemies at the battle of Armageddon and initiate a 1000-year period of world peace before ascending again to heaven with his followers.

This particular millennialist interpretation of the book of Revelation, which posits the occurrence of a 'rapture' apart from the Second Coming, derives not from traditional exegesis but instead from a relatively new, 20th-century revision of the Bible. The origins of this belief can be traced to the visions of a woman in Port Glasgow, Scotland, who in 1830 reported having seen Christ rescuing his believers before a seven-year period of 'tribulation', which was then followed by him returning to rule in peace for 1000 years (Veith, 2002). This proved to be a very attractive embellishment of scripture because it meant that Christians would not have to endure the tribulation, which is described in Revelation as a horrific period of intense suffering. Known as 'dispensational premillennialism', this version of events was popularized by preacher John Nelson Darby in the latter half of the 19th century (Boyer, 1992; Frykholm, 2004), disseminated by protestant religious tracts (Morgan, 1999) and embraced by American evangelicals following the 1909 publication of the Scofield Study Bible, which gave credence to the rapture prophecy in its 'notes' (Veith, 2002). This exegesis was further entrenched in the American evangelical community with the founding of Dallas Theological Seminary in 1924, which advanced this millennial perspective in its training of pastors (Harding, 1994).

Whereas dispensational premillennialism, as an interpretive position and a guide for religious conduct, has gained hegemonic status among American 
evangelicals, it is neither a static nor an uncontested set of beliefs. As seen in rapture literature throughout the 20th century, the mapping of prophecies onto contemporary world events, people and technologies has shifted alongside cultural values, ideologies and historical contingencies (Boyer, 1992). For example, early rapture fiction - such as Sydney Watson's books Scarlet and Purple (1913), The Mark of the Beast (1915) and In the Twinkling of an Eye (1916) - perceived as 'signs' of the Second Coming the host of social and environmental ills associated with industrialization and urban slums; these literary works concerned themselves as well with the so-called 'Jewish problem' and saw Jewish people as moving the world closer to a one-world economy that would be especially inviting for the Antichrist (Gribben, 2004). With the publication of Hal Lindsey's The Late Great Planet Earth in 1970, the harbingers of end times included the post-Second World War establishment of Israel and the nuclear face-off of the Cold War, with the Soviet Union representing the fertile soil within which evil would grow (Gribben, 2004). Finally, the Left Behind series iterates these earlier mappings within the context of a modern risk society, appealing to threats of terrorism and nuclear Armageddon, and to nationalist suspicions of international organizations, trade and currency harmonization, and religious difference. ${ }^{1}$ Indeed, nationalism and opposition to organized institutions, ranging from government agencies to the Catholic Church, run strong in Left Behind, as can be observed clearly in the books, where the UN and the Vatican serve as strongholds for the reign of evil.

It may be tempting to dismiss those who follow the series and adopt its brand of millennial prophecy as a fringe element in US religious circles. This would be a mistake that seriously underestimates the sheer numbers and influence of followers. While it may be impossible, and likely unproductive, to separate out proponents of dispensational premillennialism from those who simply read the books as fiction, there has been a notable growth in the market for apocalypse literature, or what Lynn Clark (2003) refers to as the 'dark side' of religious media, which is a cultural phenomenon worthy of investigation in its own right. Similarly, the number and political power of evangelical Christians in the US has been growing steadily, especially over the past few decades (Agnew, 2006; Davidson and Harris, 2006; Herman, 2000). Susan Harding relates that: 'dispensationalism, broadly defined, is the way most Bible-believing Christians in America read current history and the daily news' (1994: 58). Moreover, there are roughly 15 million evangelicals in the US adhering to this particular set of beliefs about the Last Days (Harding, 1994). According to other sources, the number of Americans identifying as evangelicals is estimated to be 27 percent of the population (which today would be roughly 81 million people), up from 14 percent in 1900 (Barrett, 1998). Allowing for the fact that evangelicals are radically diverse, both in beliefs and practices, there still has not been such a profound overlap between popular and Christian markets since the early 20th century (Fisher, 2003). 
The widespread interest in Christian media can be explained in part by the sheer number of evangelicals, the increasing ambiguity of religious messages in Christian media, such as 'Christian rock' music that does not explicitly mention Jesus, thereby affording increased crossover from sacred to secular markets (Hendershot, 2004), and the mass distribution of Christian products made possible by new media technologies and large retail chains.

\section{Not leaving capital behind}

The Left Behind book series is perhaps the most vibrant and visible incarnation of the apocalypse industry. Over 63 million copies ${ }^{2}$ of the books have been sold in at least 37 countries and 33 languages, rivaling the sales of books by J.K. Rowling, Dan Brown and John Grisham, and repeatedly topping the bestseller lists of the New York Times, USA Today, Barnes \& Noble and Amazon.com (Gribben, 2004; LeftBehind.com, 2006b). The spin-off products from this 16-book series are manifold: two feature films, a companion children's book series, CDs, comic books, a website, devotionals, greeting cards, computer games and more. The series has made the front cover of both Time and Newsweek magazines, and in 2002, Entertainment Weekly added the authors, Tim LaHaye and Jerry Jenkins, to its list of 'most powerful entertainers' (Fisher, 2003: 25). Finally, as a result of the book series and his other religious activities, LaHaye, who is a close colleague of televangelist Jerry Falwell, has been recognized as one of the most influential figures in the religious right movement (Eskridge, 2001). In his own words, LaHaye says that '[God] has chosen to bless the series beyond our wildest dreams' (Olson, 2005: 5).

Fear, of course, sells well. A major part of why the books sell so well may be because they represent the tensions and paranoia, the crises and instabilities, of modernity (Strozier, 1994). As Crawford Gribben observes: 'The content of these novels is marketably apocalyptic because their function is to emphasize the existing dichotomies between faith communities and contemporary life, as apocalyptic literature always has' (2004: 91). Moreover, the timing for the release of the Left Behind series could not have been more perfect. With the first book published in 1995, the series ramped up for the turning of the millennium, gaining popularity and momentum as it went, with a book published each year, and two published in 1999 alone, ringing in the new year as with the trumpet of Gabriel. By 2000, the series had sold a remarkable 20 million copies, but the flood of sales did not dissipate much after that year and, if anything, the enterprise branched out to saturate new markets with apocalypse media, including a feature film in 2001 and a sequel in 2002, both costing roughly $\$ 17$ million to produce and market (Hernandez, 2002). After the attacks of $9 / 11$, sales surged again, rising by 60 percent in the fall of 2001 alone (Gribben, 2004) as threats of terrorism amplified the public's anxiety about individual vulnerability, national preparedness, religious 
difference and social order. In Tim LaHaye's words: 'The tragedy of 9/11 just made everything [about the Left Behind story] so much more real and believable' (LeftBehind.com, 2006a). By 2005, the series had made more than $\$ 650$ million and had completely revitalized the Christian fiction market (Business Week, 2005).

Shifts in the operations and constitution of capital markets effectively mutate all sectors of production and consumption, as theorists from Karl Marx to Antonio Negri have pointed out, and the market for religious fiction is no exception. It would be too facile to say that increases in sales or numbers of books published indicate a corresponding rise in evangelical belief or interest in religious fiction, although these are two likely conclusions. But, as Heather Hendershot observes: 'Christian products have made it into the secular marketplace not only because their religious messages are ambiguous, diluted, or absent but also because they are increasingly distributed by huge, non-Christian companies' (Hendershot, 2004: 8). Markets, along with beliefs and desires, are shaped by structural forces, which must include, for this inquiry, transformations in the publishing industry.

The number of Christian book titles has grown exponentially since the mid 1990s, with some estimates indicating an 84 percent increase just in the few years leading up to the turn of the millennium (Bartholomew, 2005). Tyndale House, which is the publisher of the Left Behind series, reaped the benefits of this trend with an annual sales increase of \$135 million from 1998 to 2001 (Fisher, 2003). The corresponding profits have enabled this Christian book publisher to hire more employees, expand its warehouse space and release hundreds of new book titles per year. In the words of Kenneth Taylor, the founder of Tyndale House: 'The difficulty is to remember that the purpose of God's call to His publishers is to bring Him glory and not to make money' (in Fisher, 2003: 29).

By capitalizing upon their expanded size, and the popularity of the Left Behind series, Tyndale House has been able to tap markets previously closed to Christian publishers, allowing them to shift the distribution of their books from the majority being sold in traditional Christian bookstores to roughly 50 percent being sold in big-box stores, such as Barnes \& Noble and Wal-mart (Fisher, 2003). This movement occurred at the same time that the publishing industry was experiencing a series of mergers, leading to even larger bookseller conglomerates and the increased vulnerability of niche booksellers. Whereas prior to being sold in big-box stores Christian books were sold almost exclusively by Christian retailers, the mass distribution and popularization of rapture fiction appears to be threatening the very existence of Christian retailers. Reflecting back on sales in 2002, Steve Potratz, the founder of one Christian retailer, related: 'In my 30+ years in Christian retailing, I've never seen a tougher year than the one we just experienced. The competition for independent Christian retailers was brutal' (Fisher, 2003: 33). Feeling the threat to the Christian retail community and the discomfort of 
selling to secular stores without explicit religious missions, some Christian publishers have responded by selling only to Christian retailers or by selling only more expensive hardcover books to non-Christian stores. ${ }^{3}$ Nonetheless, as with other small retailers throughout the US and beyond, small Christian bookstores are increasingly being edged out by the big-box market.

Religious scholars and others have noted a corresponding growth in standardized, conservative content in religious fiction as an outcome of the articulation of Christian books with the big-box marketplace. The polarization of the sacred versus the secular, the saved versus the damned, apparently sells better than books delving into the heterogeneity of Christian and other religious beliefs. Censorship of titles engaging with complexity and difference, or of titles that are simply well crafted works of literature, is one apparent result (Bartholomew, 2005). Some have argued that there is a larger movement to homogenize and commercialize religious belief systems (Drane, 2000), so the conservative agenda in Christian publishing may be mirroring that trend. Thus, many religious books are never given a chance to compete in either the big-box or the traditional bookseller markets because religious publishers are catering to a conservative marketplace, if not readership. This being said, because of the diffuse nature of contemporary religious ideology, evangelical media draws diverse audiences, and the guilty pleasures associated with rapture fiction are undoubtedly supported by its presence in big-box retail settings (Clark, 2003; Frykholm, 2004).

In the fiction, the mark of the beast operates as an extension of the capitalist economy - or, more accurately, the key to buying and selling. The marketplace is what true believers must eschew to ensure their salvation. In Left Behind, the Antichrist mobilizes detailed knowledge of consumer preferences to control his subjects and battle his enemies. He circulates customized products that match the particular desires of people, thereby offering them a consumerist version of heaven on Earth (Shuck, 2004). Despite their heterogeneous packaging, these products and media deliver the same homogeneous content regarding his greatness and the obligation for obedience. The message for readers of these books, then, is to be suspicious of consumerist culture and to vigilantly guard against mind-control through products or information media, especially - it seems - if they appear to be tailored to your desires or beliefs.

Yet, in the nonfictional world of book sales, the authors are quite literally getting rich from their ventures and say that they find it difficult to remind themselves that their goal is to bring God glory, not to make money. The authors of Left Behind, along with Tyndale House and other publishers, readily exploit the mass marketplace to spread their words and increase their profits. The apocalypse industry advances by fusing with current market logics and systems, norms and forms. The resulting dissonance between messages of consumerist critique and practices of millennial consumerism is left unresolved; it is one of the few acceptable ambiguities within this genre, whereby 
riches on Earth are both a serendipitous byproduct of the larger evangelical enterprise and a validation of the dispensational interpretation of the books. From the vantage point of the late capitalist marketplace, of which this industry is a part, the prophecy must be accurate, or at least worth advancing with fervor, because the products are financially successful.

\section{Technologies of the beast}

Technology plays a crucial role in Left Behind's story and its ongoing contribution to Christian beliefs and fears about the rapture and tribulation. In the story, the most damning of all technologies is the system of surveillance referred to as the mark of the beast, which allows for the ready identification of those who follow the Antichrist. Whereas Revelation posits that the mark of the beast will be inscribed on the forehead or right hand, Left Behind, in this instance, adopts a figurative rather than literal understanding of these verses. The authors single out as the mark of the beast implantable 'biochips', which are obviously based upon nonfictional human RFID implants developed by the company VeriChip (Fisher, 2006; Monahan and Wall, 2007). In Left Behind, the biochips facilitate unique identification of individuals and the harmonization of databases for the regulation of all travel and participation in the (one-world) economy. According to The Mark, which is the eighth book in the series:

The loyalty mark ... embedded on a biochip inserted under the skin, will further identify the person to the point where every one shall be unique.... Those who neglect to get the mark when it is made available will not be allowed to buy or sell until such time as they receive it. Those who overtly refuse shall be put to death, and every marked citizen shall be deputized with the right and the responsibility to report such a one. (LaHaye and Jenkins, 2000b: 85)

Whereas the mark of the beast signifies voluntary, individual alignment with evil, it performs on multiple levels, many of which correspond with presentday information technology systems: speeding up economic transactions (Castells, 1996), ascribing trustworthy identifiers to individuals (van der Ploeg, 2005), accurately placing individuals in geographic spaces and limiting mobility outside assigned spaces (Graham and Marvin, 2001), and revealing with remarkable accuracy the consumer preferences of individuals (Turow, 2006), which are data that can be harnessed to manipulate and control, or, in the books, to eliminate people (Shuck, 2004).

The overlaps between advanced technological systems of surveillance in both fictional and nonfictional worlds cleverly help to reinforce the verisimilitude of the novels and lend validity to their interpretation of world events. Once biblical prophecies are superimposed upon new technologies, the very existence of these technologies can serve as an omen of the events described 
in the books. Whether through electronic commerce, communication, civic participation or population control, technology is increasingly regulating and foreclosing, even as it is augmenting and enabling, human activities (Monahan, 2006). Thus, one can observe the effects of 'the mark' for regulating populations in current technological systems and public policies: it is ever more difficult to purchase goods without credit cards or bank accounts; it has become incredibly dangerous and in some instances impossible to cross borders without proper national identification, which is increasingly embedded with high-tech biometric identifiers and linked to vast databases; access to public services or resources is being restricted to those who can provide official identification documents verifying citizenship; and many government employees and volunteers (such as teachers and hospital workers) have been 'deputized', or more accurately mandated, to report individuals such as illegal immigrants who try to avail themselves of public services without proper identification. Certain technologies of identification and tracking are effectively tainted, spiritually and socially, by their disproportionate application to marginalized populations. In his discussion of surveillance and the mark of the beast, David Lyon elucidates this point:

Persons on welfare, asylum seekers and refugees, these and similar groups of relatively disadvantaged persons are the first recipients of biometric and DNA measures. It is thus hardly surprising that the stigmas of criminality or poverty are a source of anxiety when similar methods are proposed for bank machines and credit cards. (Lyon, 2001: 86)

Because the readers of Left Behind books may be more conservative in their political orientation than are their secular counterparts, these resonances between prophecy and the exclusion of marginalized members of the community may not cause concern about strangers, but they do cause concern about the salvation of oneself, one's family members and one's friends (Frykholm, 2004).

In support of unambiguous binaries between the saved and the damned, the series introduces an alternative 'mark of Christ', which is a novel innovation absent from the book of Revelation. This luminescent mark appears on the foreheads of true believers and can be perceived only by other true believers. In cut-throat times of tribulation, treachery and terrorism, the attractiveness of such a reliable sign of faithful allies is easy to understand, as are the convergences with nonfictional terrorist threats and religious conflicts. When archenemies can look, and act, and talk like true believers in the novels - or like mainstream Americans, as the case may be, in the nonfictional world - a trustworthy sign system, especially one that is illegible to community outsiders, becomes the most prized possession of the army of the faithful, which is given the militaristic appellation of 'Tribulation Force'.

The series, however, briefly calls into doubt the authenticity of signs, even the most sacred of ones, thereby refracting uncertainties of modern risk societies and 
postmodern cultural sensibilities. One of the many characters with enviable computer skills, the teenage hacker named Chang, adopts both marks in order to infiltrate the Antichrist's palace and effectively operate as a spy. This renders him disturbingly ambiguous to his fellow Tribulation Force comrades, because if the marks operate as absolute, indelible and irreversible signs, how can one be both/and? In another instance, a spy named Ernie infiltrates Tribulation Force by applying a credible counterfeit mark of Christ upon his forehead. Only after his suspicious behavior calls his faith into question is the smudge rubbed off his head and his traitorous intent revealed. The series' brief flirtation with the deconstruction of static sign systems does not last long, however, but instead folds back into certitudes and clear moral distinctions, which seemingly become all the more stable because of the climate of insecurity within which they operate. As Glenn Shuck writes: 'What makes Left Behind remarkable ... is the juxtaposition of doubt and insecurity amid the familiar displays of moral certainty and spiritual chauvinism' (2004: 54). Instabilities of modern life and multiplicities of identity invite a reactionary, highly selective and widely attractive mode of fundamentalism, typified by Left Behind, which clings ever more tightly to clear marks and inflexible boundaries, as well as to the desirability of ensuring their existence (Quinby, 1994).

Thus, contradictions occur in the books' messages about the role of technology in the battle between good and evil. The mark of the beast serves as a symbolic portent of future destruction, but also as a physical embodiment of the global community - it is social control through technological means. The Tribulation Force resistance movement accordingly shuns centralized technological systems, whether of media consumption or bureaucratic management. Oddly enough, echoing popular discourse of the 1990s, the internet is presented as a pure medium, somehow democratic in nature and free of the sordid taint of the unholy. Tribulation Force therefore sparks a grassroots resistance movement by harnessing this medium to disseminate inspirational texts and organize likeminded souls against the Antichrist. Crawford Gribben elaborates:

When secure communication is possible only through the internet, [Tribulation Force member] Chloe begins her resistance to Antichrist's global hegemony by establishing an alternative economy, based on resistance to the 'mark of the beast', by developing an international Co-op.... Building a worldwide business empire is a peculiarly American method of combating the tyranny and evil of Antichrist. Her Tribulation Force partner, Ben-Judah, likewise disseminates his prophetic teaching through 'the most popular Web site in history'. (2004: 91)

It should be no surprise, then, to discover that the Left Behind franchise strives for the same degree of popularity with its online presence. Its website ${ }^{4}$ lures viewers with its graphic portrayals of destruction, its highly specialized products (e.g. for soldiers, kids, etc.), its interactive interfaces (e.g. to upload your own testimonials, reviews or prayer requests), and its range of media, including a PC game based on the series and daily devotional text messages sent to 
one's cell phone. Because evangelicals have always adopted the latest media technologies to deliver their messages (Hendershot, 2004), the authors of Left Behind should be viewed as continuing this tradition, even if the media and the messages have changed. With their explicit embracing of new media, it is not a big stretch to say that the authors fashion themselves as part of the modern-day Tribulation Force leadership, the following of which is vast, even if the threat is vague. Positioned as such leaders, the authors perceive themselves in a strangely supernatural light. Thus, in talking about the possibility of LaHaye and Jenkins being killed in a terrorist attack, Tim LaHaye says: 'I believe we're immortal until our work is done and that Jerry [Jenkins] and I've got a lot more work to do' (LaHaye and Jenkins, 2001).

Whereas the novels posit centralized databases and high-tech systems of management and surveillance as the tools of the Antichrist, decentralized communication networks are presented as inherently enabling - both of profits as well as profitable mobilization of resistance. From the books, one can discern the mark of the beast and its support structure in the technologies of the state or in bodies of international governance: with such systems, the UN automates a 0.1 percent tax on all transaction and controls populations with a supercomputer transparently named 'the Beast' (Gribben, 2004: 88). Such anti-government overtones resonate strongly with libertarian political sensibilities, encouraging readers to conclude that government bureaucracies and services, which claim to be for the public good, may actually facilitate domination of the world by the forces of evil. Rather than espouse an easy rejection of technology, however, Left Behind introduces implicit selection criteria for decentralized systems over centralize ones, for entrepreneurial programming over public programs. In this way, the books both reflect and reproduce dominant ideologies of the times, while structuring in a rationalization for the systems of production, distribution and consumption relied upon by the apocalypse industry.

\section{Saving oneself}

Perceived as a form of ideology, the dispensational premillennialism espoused by Left Behind may afford a certain egoistical detachment on the part of evangelical Christians, or a theological buffer between them and the problems of the world. If the Second Coming is preordained and those who are 'saved' will be raptured before the atrocities of tribulation occur, then the only immediate spiritual concern of Christians is with individual 'true belief' for them and their families, not with ongoing wars, genocide, famine, arms proliferation, global warming, economic vulnerability of most of the world's population and so on. ${ }^{5}$ In fact, the rapture standpoint could be seen as encouraging materialism and discouraging progressive social intervention because, paradoxically, all that is needed for salvation is true belief, so those without 
basic necessities can save themselves without profound structural changes or the economic assistance of others.

Left Behind goes so far as to align those working for social justice with evil incarnate because, in the series, these are exactly the projects engaged upon by the Antichrist to gain public legitimacy and further his dominion. Writing about this problematic in the book series, religious scholar Glenn Shuck relates:

To unbelievers [the Antichrist] seems like a saint or even the Messiah. He works to correct economic inequalities, attempts to end poverty and cure dreaded diseases, and leads the world onto a path of total disarmament. Believers, however, see through his ruse. (2004: 52)

Under the rhetorical cover of social justice and peace, the evil that is brought about by the Antichrist includes the slaughter of one-third of the world's population by phantom horsemen, a devastating nuclear attack on the United States that kills almost everyone and destroys most infrastructure, and the effective - if unknowing - enslavement of those who accept the mark of the beast and succumb to the charisma of the Antichrist.

The fatalism of Left Behind extends as well to the mark of the beast. Those who have accepted the mark of the beast cannot be saved, even if they repent, so this obviates any efforts on the part of believers to save anyone who is already damned. Believers can therefore insulate themselves from others without any moral or spiritual compunction. Remarkably, this popularized form of dispensationalism functions not only to cast doubt and suspicion upon those working toward progressive social change, because these are the tools of the Antichrist, but also to upend bedrock practices of missionizing traditionally associated with evangelicalism.

Alternative interpretations of Revelation focus on postmillennialism, meaning that Christ will not return until after 1000 years of peace have passed. By contrast, this may be a much more activist and liberal position that eschews the separatism of premillenialism by thrusting onto believers the responsibility for bringing about peace - there is no eschatological fast lane for easy escape. The difference between the beliefs of these camps explains, in part, newfound tensions between evangelicals and Catholics over the Left Behind story. Many Catholics, for instance, feel that these books dangerously propagate fear by focusing disproportionately and too intently upon Revelation to the neglect of the 'good deeds' message of the gospels (Olson, 2005; Veith, 2002).

Apparent contradictions, therefore, arise with the traditional evangelical mission of converting nonbelievers and performing good deeds, and the books' contemporary articulation of dispensationalism, which encourages and excuses self-interest, isolationism and jingoism. Because, in the novels, those who take the mark of the beast cannot be saved, saving oneself and punishing one's enemies are the only viable courses of action for believers. Similarly, for many of those Christians who believe that the rapture will occur 
prior to tribulation, the apocalypse, 1000 years of peace and Christ's return, the most important thing to do is to possess 'true belief'. Working toward social justice is not necessary and might even distract believers from their steadfast focus on their own salvation and the salvation of their family, friends or community. Schadenfreude modulates the apocalypse industry such that proponents take comfort in the salvation of believers and savor the eventual punishment of nonbelievers.

A related dissonance in the evangelical worldview occurs in the presentation of wars and human suffering. Rather than advocate for world peace, the sentiment of the apocalypse industry is that wars, especially those in the Middle East, are necessary preconditions for the Second Coming and should therefore be tolerated or supported (Agnew, 2006; Paik, 2003; Urban, 2006). This position manifests in the novels with clear expressions of anti-Semitism and frustration with Jews for not converting to Christianity, which is perceived as a necessary event for the return of Christ (Davidson and Harris, 2006). Beyond the novels, this particular exegesis may reinforce the staunch pro-Israel stance of many influential, 'Christian Right' evangelicals in the US (Herman, 2000; Mayer, 2004). In light of these observations, one can conclude that the premillennialist doctrine is mutating mainstream evangelicalism into a form of Gnosticism:

It is not repentance or brotherly love that is the defining attribute of Gnostic salvation but freedom - freedom from history, the cosmos, nature, as well as from morality itself... The Gnostic valorization of freedom at the same time articulates an exceedingly vindictive denunciation of the physical world, a condemnation far harsher than any perspective found in Christian orthodoxy. (Paik, 2003: 7-8)

On one hand, the interpretation of Revelation propounded by Left Behind deviates starkly from historical Christian beliefs in postmillennialism and traditional practices of evangelism. On the other, as Max Weber (2000) famously observed, strong affinities exist among religious beliefs and economic systems, so one should expect mutations in belief systems alongside the emergence of new forms of capital. The ideology of contemporary rapture fiction harmonizes with millennial capitalism. Rapture fiction performs a drama of extremism, consumerism, isolationism and social polarization, thereby tolerating - and arguably helping to normalize - the structural conditions and social practices that are at the root of many social problems today.

\section{Conclusion}

Left Behind embodies the tensions and complexities of modernity even though the dominant, intended meaning of its story is both straightforward and transparent. On the surface, it expresses an explicit critique of selfish, commodity-driven or 'immoral' behavior in the modern secular world. First, 
those possessing an insufficient degree of faith or who lived their lives for immediate pleasures instead of for future eternal rewards were punished by not being raptured and therefore forced to endure the trials of tribulation. Second, of those who remained on Earth, those who voluntarily aligned themselves with the devil were similarly living for the present and demonstrating extreme hostile intolerance for believers. The story tells readers that these unbelievers, all of whom have taken the mark of the beast, will be punished in the worst possible way when Christ returns to destroy them in the bloody battle of Armageddon.

This didactic storyline betrays striking similarities to long-standing myths about the suffering that must befall those who make bargains with the devil. Cultural instantiations of this narrative device can be found in Michael Taussig's (1980) study of sugar plantation workers in Columbia and mine workers in Bolivia. In these settings, the emergence of narratives and practices surrounding deals with the devil occurred in concert with the proletarianization of labor and with the particular economic and social insecurities that grew out of that process. When peasants strike secret bargains with the devil to increase production and wages in the short term, so the mythological explanation goes, those wages harbor a curse that brings bad luck upon the individual, such as barren lands, sterility and a painful, untimely death. Similarly, Left Behind enacts its own parallel cultural structure whereby those who establish pacts with the devil, whether knowingly or not, eventually suffer the consequence of damnation for all eternity. An interesting and important difference between these two renditions is that lucrative, short-term financial gains are not indicative of a devil bargain with the characters in or authors of Left Behind. Instead, devil profits are presented as being secular in nature, accrued by people with questionable 'moral values' through content or products devoid of spiritual purpose. Within this schema, conservative Christian values serve as a mark - visible only to believers - of holy capital accumulation.

Rather than attribute the immense popularity of the series simply to effective marketing, structural shifts in the bookselling industry and moral panics, one should also attend to the resonances of the books' particular dispensational premillennialism message with contemporary cultural sensibilities. Taussig writes: 'Magical beliefs are revelatory and fascinating not because they are ill-conceived instruments of utility but because they are poetic echoes of the cadences that guide the innermost course of the world' (1980: 15). From a functionalist perspective, cultures - such as those of US evangelicals - seek to integrate contradictions and dissonances, both in meaning and practice, into a coherent explanatory framework. By investigating those contradictions and dissonances, and theorizing their causes and effects, one may begin to piece together an explanation of the signification of myths such as those in Left Behind. The phenomenon of rapture fiction, in other words, should be taken seriously for the structural crises to which it may be responding 
and the hegemonic values and social relations it may be reifying and organizing, respectively.

The apocalypse industry is inflected by, and dependent upon, a particular market modality of corporate centralization, niche-market colonization and mass distribution. The apocalypse industry similarly arises from a dominant conservative religious and political culture that feeds upon fears of instability that characterize the modern world and responds with a standardized message of clear dichotomous symbols - or marks - of good and evil (Urban, 2006). Figuratively speaking, there are multiple 'beasts' being marketed here. The first beast is the character of the Antichrist and his various technologies of identification and domination. The second beast is one of palpable fear of the apocalypse, dismissal of religious difference and excited anticipation of the imminent suffering of non-Christians. The final beast is that of a millennial capitalist worldview of neoliberal policies, globalized economies and individual responsibility. The avid consumption of these beasts by readers of these books and by others may indicate something about the desirability of spiritual stabilities, even at the expense of others, as compensation for pressing social, political and material instabilities marking societies today.

It is between the messages of rapture media and the mode and context of their transmission that interesting dissonances occur. In Left Behind, the world economy may serve the interests of evil, but the apocalypse industry is thoroughly integrated with the capitalist economy and is amazingly lucrative. Media and networking technologies may be the tools of the Antichrist, but they are also the tools of the authors and the novels' heroes. The intent of the authors and of evangelists more generally may be to save souls, but the message of the books is to insulate oneself against nonbelievers and eschew social justice because the damned cannot be saved and the end is near. The result may be a dangerous rationalization of social inequalities that elevates the logics of the neoliberal economy to the level of the sacred.

\section{Notes}

1. The 'Jewish problem' also returns with the narrative necessity of converting 144,000 Jews to Christianity as a precondition for the Second Coming of Christ, lending the novels a decidedly anti-Semitic overtone, which has been interpreted as an intolerance for religious pluralism more generally (Frykholm, 2004; Mleynek, 2005).

2. This staggering figure includes children's books, graphic novels and audio books.

3. For instance, when I assigned the book The Spychips Threat: Why Christians Should Resist RFID and Electronic Surveillance for a class of mine, I was surprised to receive a phone call from the publisher telling me that, because my university was not 'Christian', the publisher would sell only the hardcover version of the book to students, even though the paperback was easily available at Christian stores and - paradoxically - from online venues like Amazon.com.

4. http://leftbehind.com/ 
5. This position may represent a departure from the sermons of 1980 s televangelists, such as Billy Graham, who did argue for overt political engagement in matters extending beyond 'moral values', including nuclear disarmament, among other things (Harding, 1994).

\section{References}

Agnew, J. (2006) 'Religion and Geopolitics', Geopolitics, 11(2): 183-91.

Barrett, D.B. (1998) 'A Century of Growth', Christianity Today November: 50-1.

Bartholomew, R. (2005) 'Religious Mission and Business Reality: Trends in the Contemporary British Christian Book Industry', Journal of Contemporary Religion 20(1): 41-54.

Bible: King James Version (2006) URL (consulted December 2006): http://www.hti.umich.edu/k/kjv/

Boyer, P.S. (1992) When Time Shall be no More: Prophecy Belief in Modern American Culture. Cambridge, MA: Belknap Press of Harvard University Press.

Business Week (2005) 'The Fashion of the Christ', BusinessWeek Online 23 May.

Castells, M. (1996) The Rise of the Network Society. Cambridge, MA: Blackwell.

Clark, L.S. (2003) From Angels to Aliens: Teenagers, the Media, and the Supernatural. New York: Oxford University Press.

Comaroff, J. and J.L. Comaroff. (2000) 'Millennial Capitalism: First Thoughts on a Second Coming', Public Culture 12(2): 291-343.

Davidson, C. and J. Harris. (2006) 'Globalisation, Theocracy and the New Fascism: The US Right's Rise to Power', Race \& Class 47(3): 47-67.

Drane, J. (2000) The McDonaldization of the Church. London: Darton, Longman and Todd.

Eskridge, L. (2001) 'And the Most Influential American Evangelical of the Last 25 Years Is ...' Evangelical Studies Bulletin 17: 1-4.

Fisher, A. (2003) 'Five Surprising Years for Evangelical-Christian Publishing: 1998 to 2002', Publishing Research Quarterly summer: 20-36.

Fisher, J.A. (2006) 'Indoor Positioning and Digital Management: Emerging Surveillance Regimes in Hospitals', pp. 77-88 in T. Monahan (ed.) Surveillance and Security: Technological Politics and Power in Everyday Life. New York: Routledge.

Frykholm, A.J. (2004) Rapture Culture: Left Behind in Evangelical America. New York: Oxford University Press.

Graham, S. and S. Marvin (2001) Splintering Urbanism: Networked Infrastructures, Technological Mobilities and the Urban Condition. New York: Routledge.

Gribben, C. (2004) 'Rapture Fictions and the Changing Evangelical Condition', Literature \& Theology 18(1): 77-94.

Harding, S. (1994) 'Imagining the Last Days: The Politics of Apocalyptic Language', pp. 57-78 in M.E. Marty and R.S. Appleby (eds) Accounting for Fundamentalisms: The Dynamic Character of Movements. Chicago: University of Chicago Press.

Hendershot, H. (2004) Shaking the World for Jesus: Media and Conservative Evangelical Culture. Chicago: University of Chicago Press.

Herman, D. (2000) 'The New Roman Empire: European Envisionings and American Premillennialists', Journal of American Studies 34(1): 23-40.

Hernandez, G. (2002) 'Proving the Market in Faith-based Films', San Diego UnionTribune 18 October: E-4. 
LaHaye, T. F. and J.B. Jenkins (2000a) Left Behind: A Novel of the Earth's Last Days. Wheaton, IL: Tyndale House Publishers.

LaHaye, T.F. and J.B. Jenkins (2000b) The Mark: The Beast Rules the World. Wheaton, IL: Tyndale House Publishers.

LaHaye, T.F. and J.B. Jenkins (2001) 'Planned Television Arts Teleprint Conference: Interview with Tim LaHaye and Jerry Jenkins', URL (consulted December 2006): http://www2.jsonline.com:80/lifestyle/religion/oct01/endtrans102301.asp?format $=$ print

LeftBehind.com (2006a) 'Frequently Asked Questions', URL (consulted September 2006): http://www.leftbehind.com/channelhelpinfo.asp?channelID=93

LeftBehind.com (2006b) 'The Facts', URL (consulted September 2006):

Lyon, D. (2001) Surveillance Society: Monitoring Everyday Life. Buckingham: Open University Press.

Mayer, J.D. (2004) 'Christian Fundamentalists and Public Opinion Toward the Middle East: Israel's New Best Friends?', Social Science Quarterly 85(3): 695712.

Mleynek, S. (2005) 'The Rhetoric of the "Jewish Problem" in the Left Behind Novels', Literature and Theology 19(4): 367-83.

Monahan, T. (ed.) (2006) Surveillance and Security: Technological Politics and Power in Everyday Life. New York: Routledge.

Monahan, T. and T. Wall. (2007) 'Somatic Surveillance: Corporeal Control through Information Networks', Surveillance \& Society 4(3): 154-73.

Morgan, D. (1999) Protestants and Pictures: Religion, Visual Culture and the Age of American Mass Production. New York: Oxford University Press.

Olson, C.E. (2005) 'Will Catholics Be "Left Behind"?: The "Rapture" and the Left Behind Books', Catholic Scripture Study, International 1: 1-12.

Paik, P.Y. (2003) 'Smart Bombs, Serial Killing, and the Rapture', Postmodern Culture 14(1): 1-17.

Quinby, L. (1994) Anti-Apocalypse: Exercises in Genealogical Criticism. Minneapolis, MN: University of Minnesota Press.

Shuck, G.W. (2004) 'Marks of the Beast: The Left Behind Novels, Identity, and the Internationalization of Evil', Nova Religio: The Journal of Alternative and Emergent Religions 8(2): 48-63.

Strozier, C.B. (1994) Apocalypse: On the Psychology of Fundamentalism in America. Boston, MA: Beacon Press.

Taussig, M.T. (1980) The Devil and Commodity Fetishism in South America. Chapel Hill, NC: University of North Carolina Press.

Turow, J. (2006) Niche Envy: Marketing Discrimination in the Digital Age. Cambridge, MA: MIT Press.

Urban, H.B. (2006) 'America, Left Behind: Bush, the Neoconservatives, and Evangelical Christian Fiction', Journal of Religion \& Society 8: 1-15.

van der Ploeg, I. (2005) The Machine-readable Body: Essays on Biometrics and the Informatization of the Body. Maastricht: Shaker.

Veith, G.E. (2002) 'When Truth Gets Left Behind', Christian Research Journal 24(4): 11-19.

Weber, M. (2000) The Protestant Ethic and the Spirit of Capitalism. New York: Routledge.

Torin Monahan is Associate Professor of Human and Organizational Development and Associate Professor of Medicine at Vanderbilt University. He is editor of Surveillance and Security: Technological Politics and Power 
in Everyday Life (200) and author of Globalization, Technological Change and Public Education (2005). His main theoretical interests are in social control and institutional transformations with new technologies. Additional interests include globalization, urban studies, social inequality and contemporary social and cultural theory. Address: Vanderbilt University, Department of Human and Organizational Development, Peabody College \#90, 230 Appleton Place, Nashville TN 37203-5721, United States.

[email: torin.monahan@vanderbilt.edu] 